\title{
DESIGN OF SALES PERFORMANCE DASHBOARD BASED ON SALES FUNNEL \& SALES FORCE AUTOMATION THEORIES: A CASE OF AN INDONESIAN ISLAMIC BANK
}

\author{
Mardhiah Gani \\ Department of Industrial Engineering \\ Hasanuddin University, Gowa, Indonesia \\ E-mail: mardhiah19d@student.unhas.ac.id \\ Dhttps://orcid.org/0000-0003-2797-959X \\ Rosmalina Hanafi \\ Department of Industrial Engineering \\ Hasanuddin University, Gowa, Indonesia \\ E-mail: rhanafi@unhas.ac.id \\ iD https://orcid.org/0000-0002-5134-3906 \\ Kifayah Amar \\ Department of Industrial Engineering \\ Hasanuddin University, Gowa, Indonesia \\ E-mail: kifayah.amar@unhas.ac.id \\ (iD https://orcid.org/0000-0002-8000-9712
}

Received: September 22, 2021

DOI: 10.46281/ijibfr.v8i1.1527
Accepted: November 30, 2021

Online Published: December 31, 2021

URL: https://doi.org/10.46281/ijibfr.v8i1.1527

\begin{abstract}
One of the bank management concerns related to sales performance is ensuring sales people perform the sales process correctly. Unfortunately, most sales people have problems in the sales process, which causes their low performance. Islamic banks in Indonesia also experienced this situation, so a strategy needs to overcome this problem. For instance, using surveillance tools such as Sales Force Automation (SFA) with sales funnel theory. An SFA tool is a sales system connected to computers and internet networks. It monitors sales processes and results, manages contacts, forecasts sales, and analyzes sales performance daily and monthly. Additionally, it helps sales forces to measure the ability to achieve targets, plan sales strategies and customer approaches, and increase work motivation. Also, raise awareness of developing skills, and provide up-to-date information to supervisors about sales force performance to determine the proper training. Therefore, the use of SFA tools is expected to increase the productivity of sales people in optimizing the fulfillment of deposit targets in Islamic banking. This paper reports the SFA design in the form of a dashboard model with a visual sales to funnel that shows the function of the salesperson in conducting the sales process ends with the results.
\end{abstract}

Keywords: Islamic Bank, Performance, Sales Force Automation, Sales Funnel.

JEL Classification Codes: D40, E50, M31. 


\section{INTRODUCTION}

The market share of Islamic banking in Indonesia was only 5.96\% in 2018, with a Muslim population spread of $86.7 \%$ or 231 million people out of a total of 266 million Indonesian people (Financial Services Authority, 2018). The Financial Services Authority (known as OJK in Indonesia) acknowledges that several challenges are affecting Indonesia's financial services industry, such as lack of number and competence of human resources and IT. Also, the products offered are limited in number, services that do not meet customer expectations, and low public understanding and awareness (Department of Islamic Banking, 2015). Therefore, improvements in several lines in Islamic banks become essential in particular for the HR and technology aspects. Further, it will improve the performance of Islamic banking.

One author of this paper recently found a case in an Islamic bank regarding not having a system to monitor the sales process and results. In this case, the design of the monitoring process and sales results are expected to help improve the sales team's performance, thus indirectly helping increase the market share growth of Islamic banks in Indonesia.

The researchers acknowledge the formation of several relationships with customers during the sales process, concluding that relationship-oriented sales were the key to business growth (Borg \& Young, 2014). According to Berry (2002), relationship marketing was an activity to attract, maintain, and improve customer relationships. Today, organizations have proven the benefits of technology in increasing sales force efficiency and effectiveness, including adapting and exploring various dimensions of technology for access, analyzing, and presenting information to all sales aspects (Agnihotri \& Rapp, 2010).

To manage the performance and activities of the company, a manager needs the correct information provided at the right time related to team member performance (Stoop, 2009). Therefore, an information system or data visualization is needed for these purposes. Data visualization is a visual context or graph used to understand data; this data visualization can help various financial institutions make decisions (Baysan et al., 2005). One example of visual data developed is dashboard marketing, where it has been introduced in recent years to bring a company's marketing metrics into a single view (Pauwels et al., 2009).

One of the most powerful tools to improve marketing performance in companies is Sales Force Automation (SFA). SFA is a computerized system that provides sales people and sales managers information in finding sales prospects, managing contacts, monitoring customer relationships, controlling sales processes, scheduling meetings, predicting sales, and analyzing team member performance (Baysan et al., 2005). The benefits of SFA have been discussed in previous studies as found in Jelinek (2013), Barker et al. (2009), Rostamian and Sadrabadi (2016), and Malek et al. (2018)

In this study, the creation of this dashboard design follows the SFA theory with the primary goal of monitoring sales force performance. The sales force performance can be evaluated from the sales process, results, and sales force quality measurements. Meanwhile, the sales process adheres to the sales funnel management theory, starting with a series of data from the sales pipeline. Yan et al. (2015) stated that, in general, the pipeline operation model was to identify new marketing prospects. Next, the salesperson enters the marketing prospect opportunities in the pipeline management system. The identified prospect opportunities were then evaluated and determined by several people who became the marketing targets. As is well known, a marketing opportunity consists of a set of one or more products or services that the salesperson seeks to convert into actual customer purchases.

On the other hand, the sales funnel was a sales process that must treat like a production process (Roff-Marsh, 2004). Therefore, the company must carry out a sales process such as a production process, consisting of a coordinated arrangement of activities that firmly convert raw materials (Lead) into finished goods (Closed Sales). The word "funnel" was used to describe the detailed shape of the cone, 
where the contacts were collected upstream of the sales funnel, then moved to the following sales process. In the next stage of the sales funnel, these contacts begin to fall so that several customers successfully purchase the product or service in the neck of the sales funnel (Grublješič \& Čampa, 2016). This dashboard combines the benefits of SFA with a visual display of the sales pipeline and sales funnel management that will make it easier for the sales force and supervisors to monitor the sales process and results.

Several data visualization tools are developed in the application of business intelligence for business analysis in different companies. The devices were different even though they had the same goal of data visualization (Beltran et al., 2021). Research conducted by Boujena et al. (2009) discussed SFA benefits from a customer perspective. This study was the first to examine the benefits of using SFA from a customer perspective. The result of this study was that customers perceive benefit from the four main dimensions of their interaction with salespeople, i.e. professionalism, frequency of interaction with customers, the responsiveness of salespeople, and quality of salespeople's relationships with customers. Another study conducted by Baysan et al. (2005) discussed the development of SFA tools using Business Process Management (BPM) software. BPM can identify more detailed sales processes, analyze reports, models to determine probabilistic results from the sales process, and decision-analytic models to optimize sales.

Furthermore, Dissanayaka (2019) introduced a mobile-based SFA system to log in and enter sales orders anywhere, even if they do not have an internet connection. The system directly helps increase productivity and helps to provide better customer service across the island and localizes the system. This system is primarily helpful for salespeople located in rural areas.

\section{Problem Identification}

\section{METHODS}

The design of a sales monitor tool was conducted because there was no monitoring tool used to monitor sales force activities in one of the Islamic banks in Indonesia. So far, the device used was a simple sales pipeline in the form of sheets of paper containing a list of data on the names of potential customers, volumes, and types of products that were not recorded properly. Moreover, the sales pipeline did not describe the sales process and results. As a result, the progress of the sales process was not visible, so the sales force did not have a sales plan. In addition, they could not monitor sales results daily, so they did not know how many additional sales they needed to reach the target. From the analysis of the problem, it was decided to create a sales force monitoring tool, which can accommodate the sales force's needs in conducting sales activities, and supervisors can also monitor sales force activities on a daily, weekly, and monthly basis. The dashboard design was made using excel software connected to the internet network, adapted to the theory of SFA. The dashboard was designed with the objectives such as directing the work goals, managing the workflow (sales pipeline and sales funnel management), and visually displaying the sales process, sales results, and required quality performance measures, as described below.

\section{Objective of Design}

The purpose of designing a monitoring tool for salespeople is to assist in predicting, organizing, planning, and monitoring sales activities and sales results daily and monthly. Thus, the supervisor can see the sales process, achieve sales results, monitor productivity, and determine improvements to the sales force.

\section{Organize Workflow}

Determining the device's design can accommodate the flow of sales force activities, namely before sales, on sales, and after-sales. Before sales activities begin, include determining the target number of current 
months and planning bids by gathering multiple names of potential customers, potential funds, product types, approach types, and estimated closing times. These data sets are included in what the Sales Pipeline calls the target bid, which the sales force will execute with a predictable execution time plan. On sales, activities emphasize sales execution by paying attention to the sales process stages, from prospective customers to becoming customers.

The sales process where there is an arrangement, planning for moving stages from upstream to downstream to closing or winning is usually called Sales Funnel management. In this case, the sales force can set a strategic approach to convert the sales pipeline into wins, while the percentage of winning conversions is as much as possible or following the targets determined at the beginning. The names of the determined sales funnel stages are Leads, Prospects, Interested, Closeable, and Won. After-sales activities emphasize analyzing the results of the sales process and sales results. The sales process results show the results of the sales funnel management where the sales force's ability to win can be seen from the number of offer leads; how many leads can win?. Sales results show the volume of sales that have been won. Analysis of sales results provides rewards, punishments, coaching, mentoring, and training in after-sales activities.

\section{Visualize the Sales Process and Sales Results}

Several monitoring tools used in most companies focus on monthly sales results. As a result, supervisors and sales forces can see sales results only at the beginning of the month in the following month. In this study, the monitoring tool designed by displaying up-to-date visuals of the sales process and results daily and monthly.

\section{Measuring the Sales Force Performance}

Sales process and sales result are two indicators used to measure sales force performance. The quality of the sales process can be seen from the number of offers, won conversions, cross-selling rates, won visit rates, and won call rates. Meanwhile, the quality of sales results can be seen from the volume, retention rate, and performance rate (see Table 1).

Table 1. Sales process and its performance

\begin{tabular}{|c|c|c|c|}
\hline Factor & Indicator & Target & Time \\
\hline \multirow{4}{*}{ Sales Process } & Number of Offers & As high as possible & \multirow{2}{*}{ As high as possible } \\
\cline { 2 - 3 } & Conversion Rate & Ash & \multirow{3}{*}{ Per month } \\
\cline { 2 - 3 } & Cross-Selling Rate & As high as possible & \\
\cline { 2 - 3 } & Won Visit Rate & As high as possible & \\
\cline { 2 - 3 } Sales Result & Won Call rate & As high as possible & \\
\cline { 2 - 3 } & Volume & As targeted & \\
\cline { 2 - 3 } & Retention Rate & $100 \%$ & \\
\cline { 2 - 3 } & Performance Rate & $100 \%$ & \\
\hline
\end{tabular}

The SPM dashboard helps the sales force and supervisors to identify sales activities and sales progress with the following objectives:

- Predict sales results to exceed the target through collecting customer data into several leads to be executed

- Planning sales by creating data leads, commonly called a sales pipeline

- Help arrange the next customer visit and analyze how it will be delivered to the lead 
- Manage the process through sales activities in the pipeline, and ensure the progress of the sales from each lead that has been executed according to the sales funnel rules

- Controlling the progress of achieving targets through the sales process results by reviewing them daily, weekly, and monthly basis

- Help analyze the weaknesses and strengths of the sales force in the sales process to produce a systematic way of coaching, training, and monitoring

- Improve sales force performance by directing activities following company targets

- Increase sales force awareness in managing themselves, time, and work according to targets.

\section{RESULTS}

The design was called Sales Pipeline Mapping Dashboard (SPM Dashboard), as presented in Figure 2. It consists of input tables and visual displays created using excel software connected to the internet network where the sales force can input data anywhere. The monitoring can be done daily, weekly, or monthly. Here is the SPM Dashboard design:

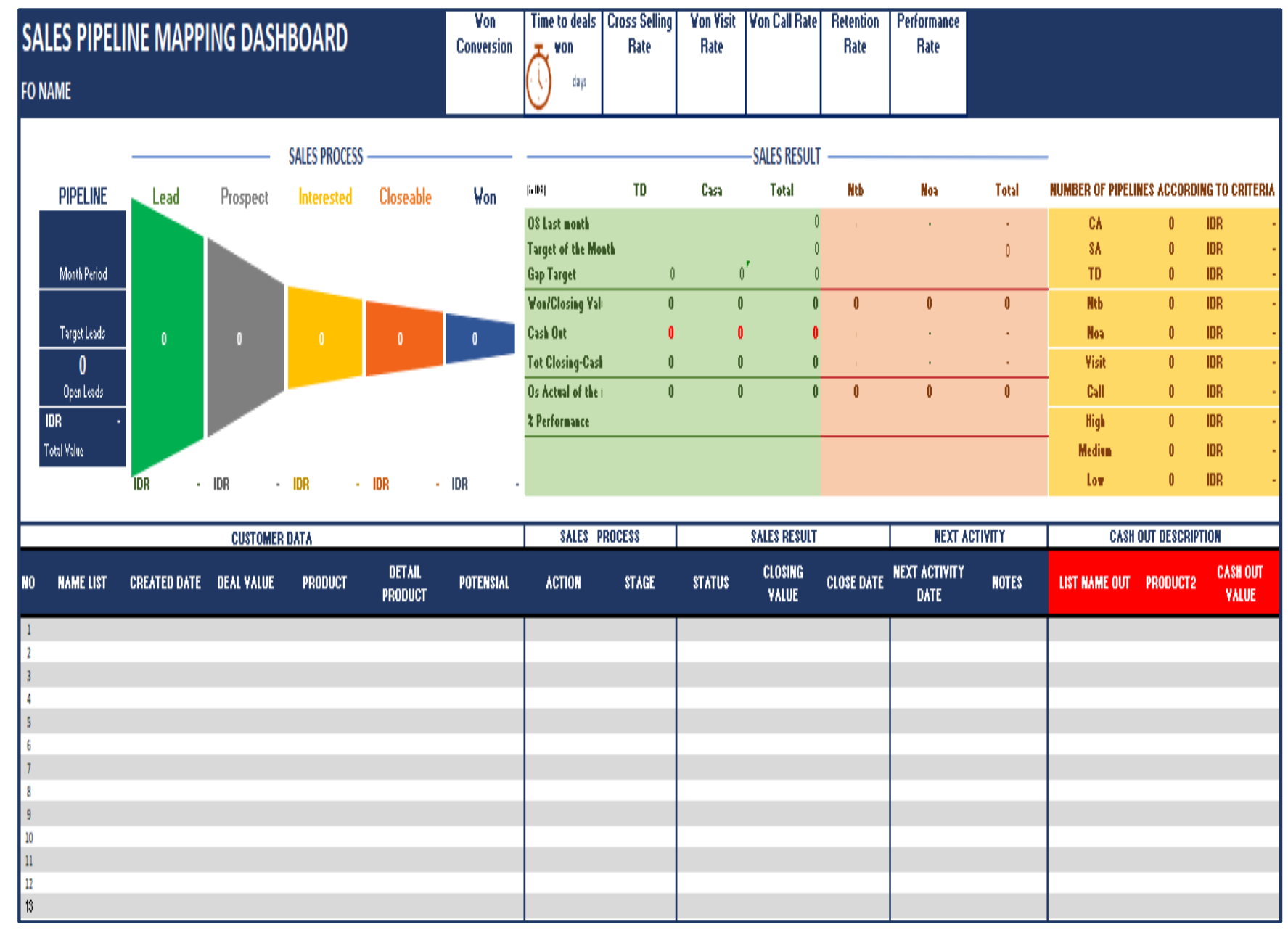

Figure 1. Customer data input menu

\section{Input Table}

The input table consists of customer data, sales process, results, subsequent activities, and descriptions of cash. 


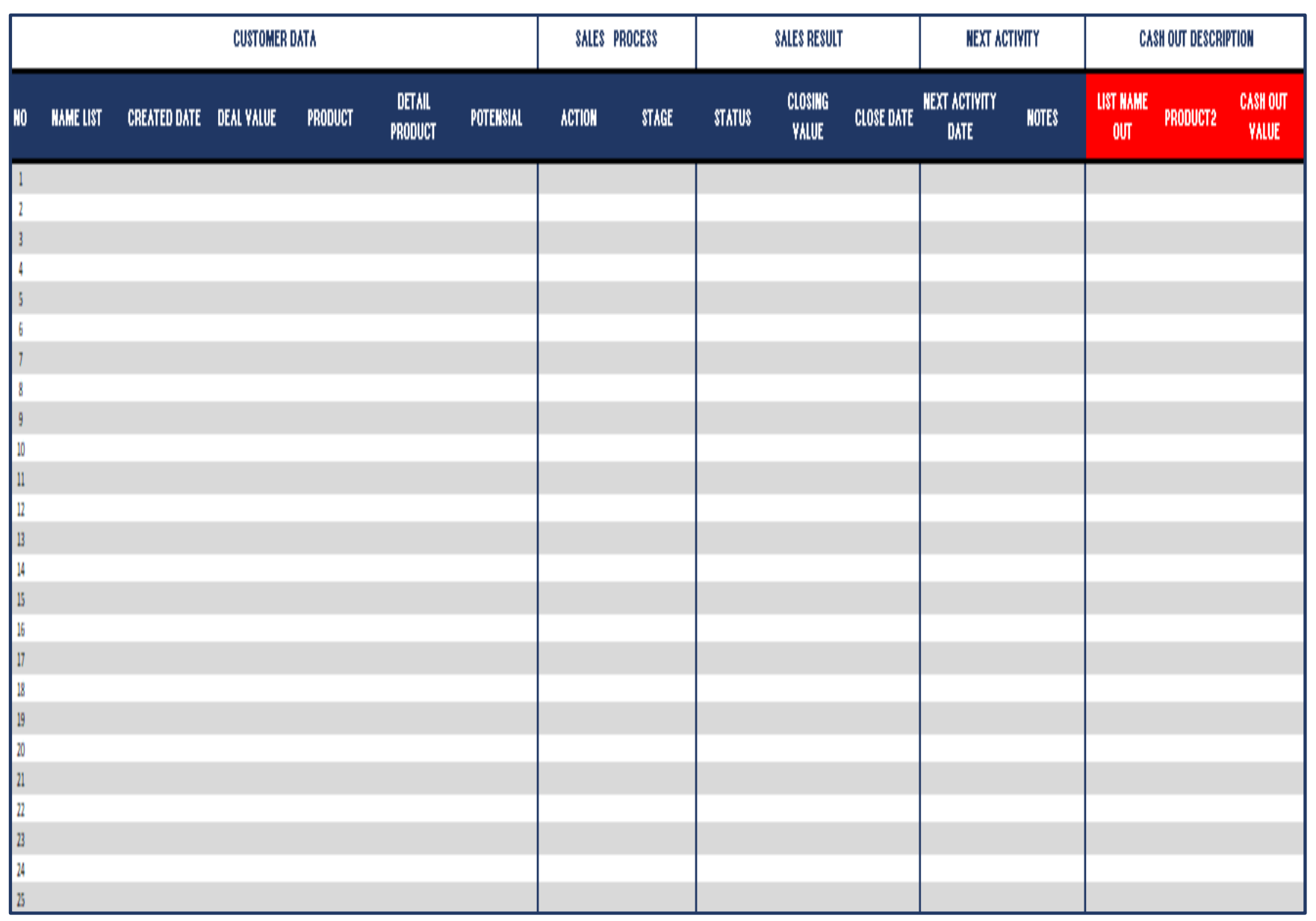

\section{Customer Data}

Figure 2. Sales Pipeline Mapping Dashboard Model

Customer data contains prospective customers or current customers who become leads for prospecting. The required data input is the name of the customer (name list), prospect plan date (created date), the volume of funds predicted to be closing (Deal Value). Also, the kind of product (TD, CA, SA); product detail (Noa, Ntb, or Top-Up); and potential customers are categorized in terms of the number of funds that are high, medium, and low.

\section{Sales Process}

This menu is the stage of the sales process, where the sales force will input the sales process through offerings to customers who are prospects. Input processing carried out is Action and Stage columns. The action column is the action or activity of the sales force in making sales consisting of Call, Visit, and Presentation. While in the Stage column that follows the rules of the sales funnel are Leads, Prospect, Interested, Closeable, and Won. The results of the sales process input will appear in the visual sales process in the form of a sales funnel.

\section{Sales Result}

This menu results from a sales process menu consisting of Status, Closing Value, and Close Date columns. The Status column contains the description Won, while the Closing Value column describes the amount of Won funds, and the Close Date column includes the date of the closing transaction. 


\section{Next Activity}

The next Activity menu records the process results for the next meeting plan so that the sales force can monitor and alert customers to the next appointment.

\section{Cash-Out Description}

This menu is a collection of names of customers who make withdrawals in the current month, thus helping the sales force monitor the movement of funds towards achieving the target.

\section{Visual Display}

The visual display consists of sales processes, results, pipeline details, and performance quality measures. This display is also an analytical tool to measure and monitor sales force productivity and performance.

\section{Sales Process}

This figure results from inputting a sales process table based on sales funnel theory. The terms at each stage followed terms that are commonly used in banking. The funnel model is made in the horizontal form where the size of the Lead stage is larger than others, which describes the number of more prospective customers in this stage, then decreases to produce Won (Closing).

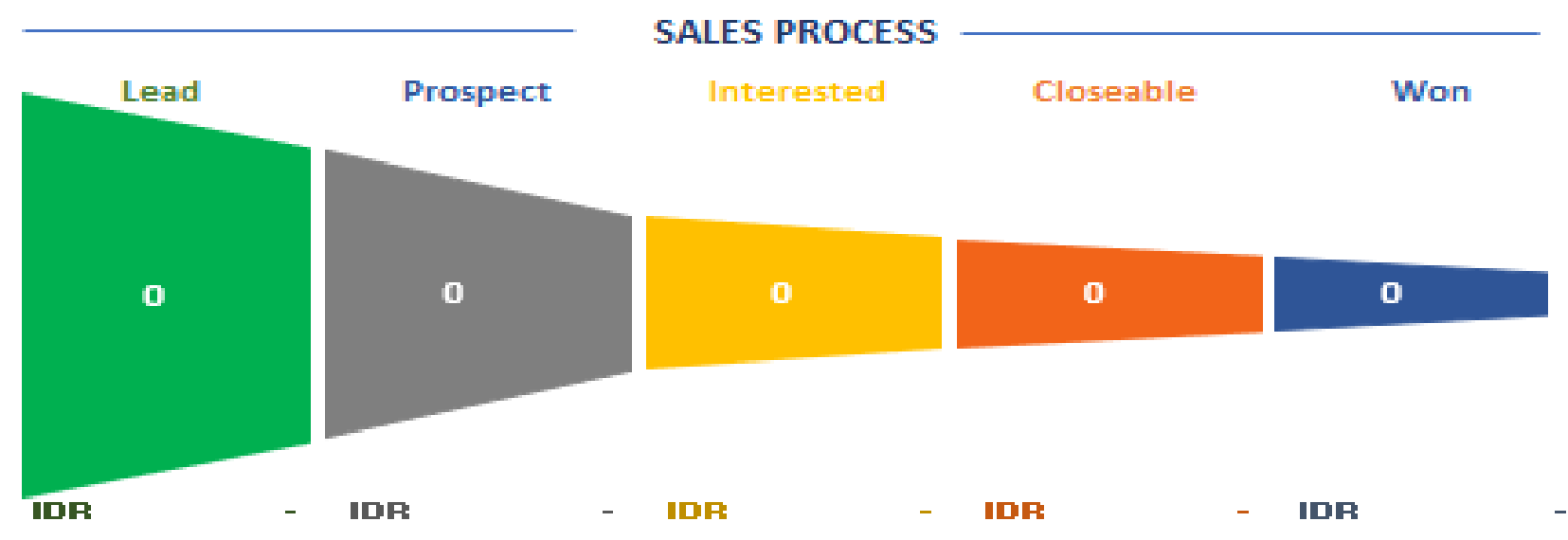

Figure 3. Display of Sales Process

Leads are when the potential customers and the volume of funds have been collected. This list becomes a sales plan for one month that is input in the SPM system one day before entering the next month to ensure that the sales force is ready to conduct sales activities early.

Prospect/Approach is an advanced stage where the sales force executes prospective customers by conducting sales activities. This stage aims to build a foundation of relationships with customers through questions about customer needs and solve problems. This stage consists of sub-stages, including making appointment plans, proposal submissions, presentations, or face-to-face visits. This stage can take several visits or one visit to switch to the interested stage, depending on the customer's needs or the ability of the sales force to influence the customer. 
Interested, at this stage, the customer is interested in the offer submitted by the sales force and has promised the following meeting to close the offer by determining the product desired by the customer. Sometimes at this stage, the customer immediately agrees to close this offer.

Closeable, for this stage, the customer has promised to place funds or has agreed to buy and wants to join the offer from sales force by filling out several forms.

Won (closing), at this stage, the customer has submitted some funds to have savings or add to the previously registered savings balance.

Analyzing the development of the sales process from the sales force every day can be done by paying attention to the sales funnel image, namely by looking at the number of prospective customers entered at the lead's stage and how many prospective customers moved to the prospect stage. Next, how many prospective customers switch to the interested stage, then how many prospective customers move to the closeable stage, and finally, how many prospective customers succeeded in becoming customers. The accumulation of leads in one stage or slow movement stage can be the subject of discussion between supervisors and the sales force in coaching, mentoring, or training.

\section{Sales Result}

The table below shows the results of inputting the sales result table, which is the value of achieving the targeted product variables, namely TD (Time Deposit), Casa (Current Account and Saving Account), Ntb (New to bank), Noa (Number of accounts). As for the details, they are:

- Outstanding (OS) last month was the volume of achievements of the current month

- This month's target is the target for the current month that has been set by management and discussed at the time of goal setting

- The target gap is the reduction in the actual value of last month against this month's target, which displays how much the difference in the actual target for the current month is, whether it is more or less

- Won/closing value is the value of funds that successfully close the offer or add to the balance in the account

- Cash Out is the value of funds issued or withdrawn in the current month

- Total closing cash-out is the real closing value after deducting the funds that came out in the current month

- This month's Actual OS is the sum of last month's OS with the total value of Closing cash-out, which is the actual achievement of the sales force in the current month

- \% Performance is the percentage of successful closing compared to the total target

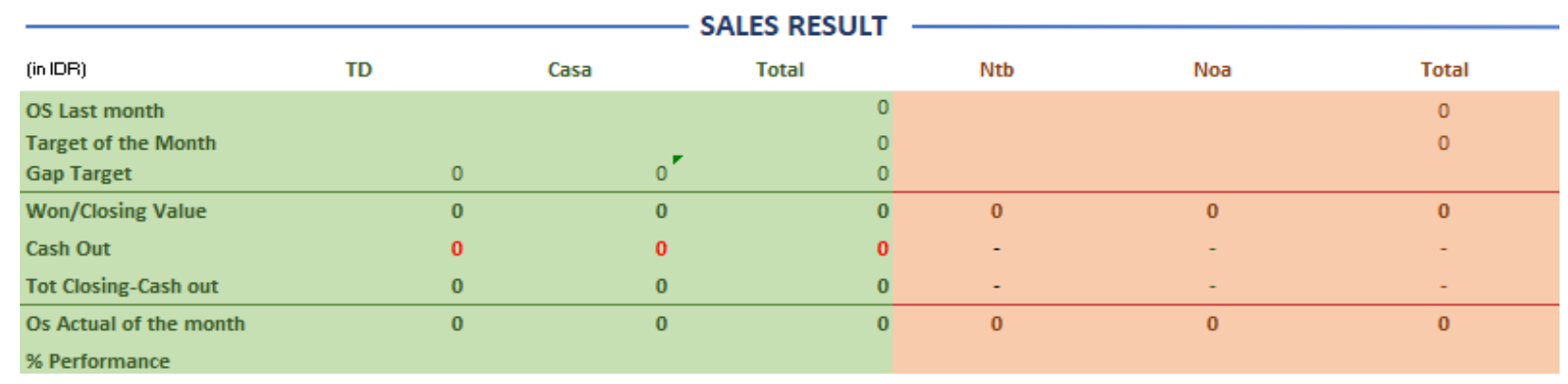

Figure 4. Display of Sales Result 
Analyzing sales results is the most critical aspect; supervisors and sales force can see the progress of achieving targets daily and taking into account the target time to meet funding targets. Coaching from a supervisor is vital to ensuring the sales force can achieve its goals by providing motivational and strategic approaches to potential customers. From Figure 4, the sales force can analyze the lack of targets and the remaining time to achieve them. In addition, supervisors can use this display to analyze sales force performance, namely from the difference between the target volume and the achievement of TD volume, Casa volume, number of Ntb accounts, and number of Noa accounts, with consideration to the target time.

\section{Measurement of Sales Force Performance}

This measure is an analysis tool to determine the sales force performance through Won conversion rate, Time to deals to won, cross-selling rate, won visit rate, won call rate, retention rate, and performance rate. Won conversion rate is the percentage of the sales force's ability to close an offer of leads. The Time to deal with won is to know the average time it takes for a sales force to close an offer. Cross-selling rate is the percentage of offering other products to existing consumers. Won visit rate is the percentage of the sales force's ability to close offers from some visited leads. Won call rate is the percentage of the sales force's ability to complete an offer from the number of leads in the call. Finally, the retention rate is the sales force's ability to hold funds from exiting, and the performance rate is the percentage of achievement of the target fund. Here, performance rate is the percentage of successful closing compared to the total target.

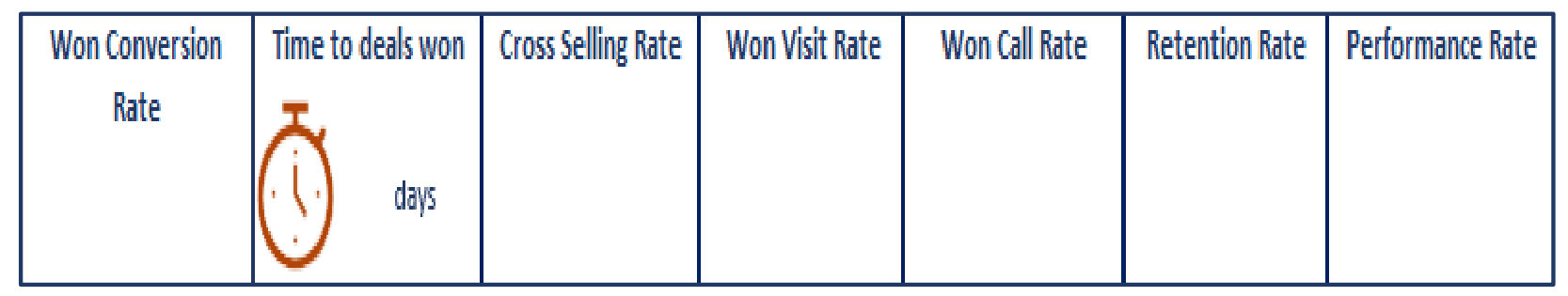

Figure 5. Display of sales force performance

Display in Figure 5 can be used as a performance analysis tool, the target size to be achieved at won conversion rate, cross-selling rate, won visit rate, won call rate is as high as possible. The higher the performance percentage, the more leads are closing, so the more manageable the funding target is achieved. The time target for a won deal is measured by a shorter closing time, which indicates an increase in sales force skills. While, the target measure of retention rate and reasonable performance rate is $100 \%$.

\section{Pipeline Detail}

Visual pipeline details are a recapitulation of the number of accounts and nominal funds on Current Account (CA), Saving Account (SA), Time Deposit (TD), New to Bank (Ntb), Number of Account (Noa). Also, Visit, Call, High, Medium, and Low are included in the list of leads. 


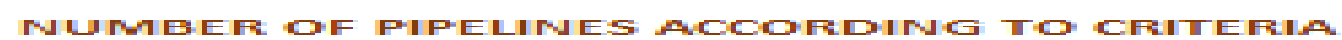

\begin{tabular}{|c|c|c|c|}
\hline$E \pi$ & $\square$ & $1 \mathrm{FE}$ & - \\
\hline $5 \mathrm{~m}$ & $\square$ & $\triangle D F E$ & - \\
\hline דய & $\square$ & $\triangle D F$ & - \\
\hline FIEE & 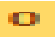 & IDFE & - \\
\hline IDOE & $\square$ & IDFE & - \\
\hline wisit & $\square$ & $1 \mathrm{CP}$ & - \\
\hline EaII & $\square$ & $10 \mathrm{Fe}$ & - \\
\hline HiEh & $\square$ & $\triangle 10 \mathrm{Fe}$ & - \\
\hline NATEAfurm & 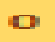 & $\triangle D F$ & - \\
\hline Lanur & $\square$ & $1 \mathrm{CFE}$ & - \\
\hline
\end{tabular}

Figure 6. Display of pipeline data

The use of the SPM Dashboard follows the flowchart diagram as shown below:

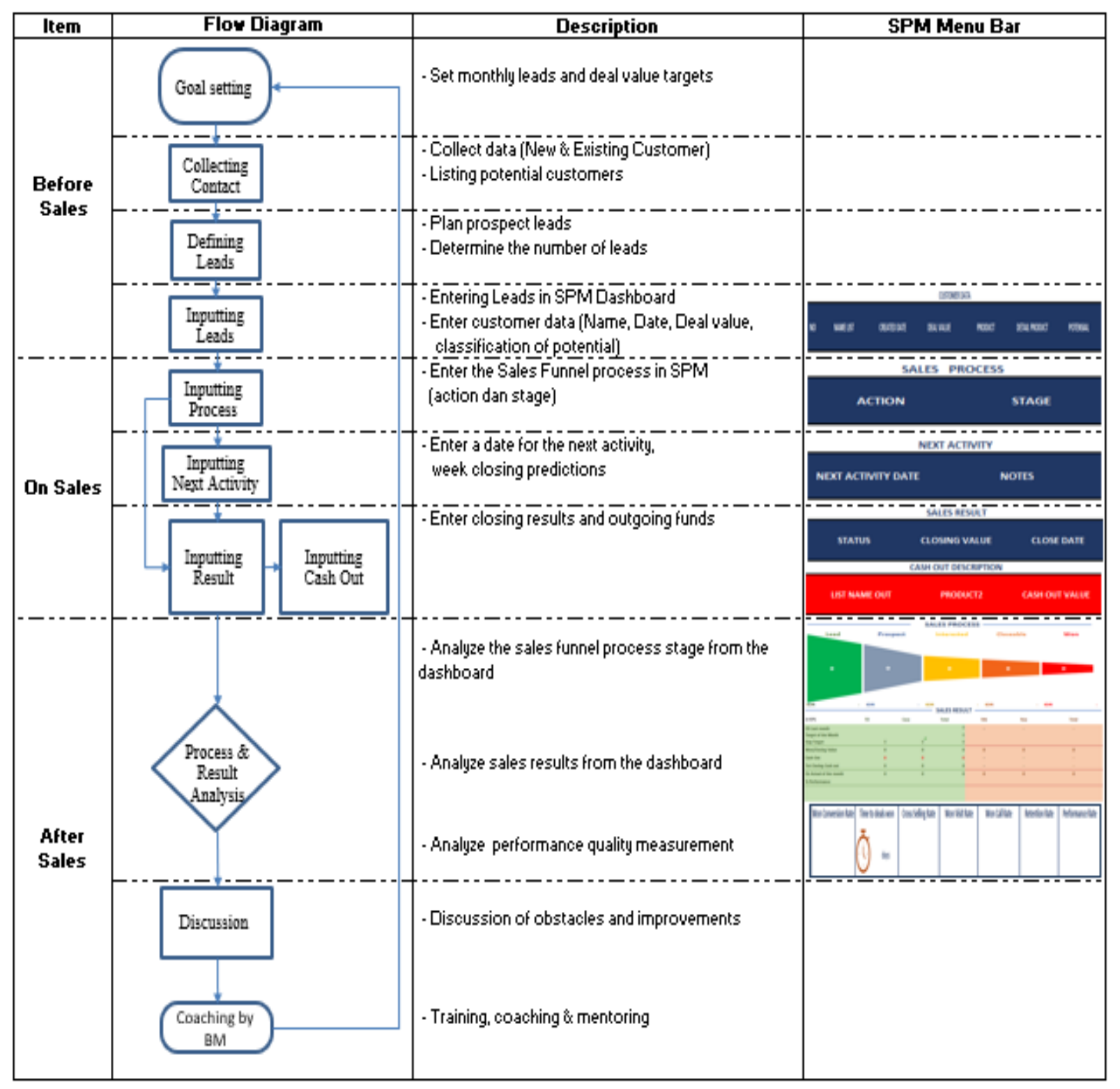

Figure 7. Flowchart diagram of the dashboard SPM input process 


\section{DISCUSSION \& CONCLUSION}

The application of data visualization in the banking sector helps make business performance better and understand related information through visual data interaction. Some researchers design data visualizations or dashboards for use at different companies. For example, Boujena et al. (2009) discussed the benefits of using automation systems to support sales forces from customer perspectives. Baysan et al. (2005) developed SFA tools in a software company using Business Process Management (BPM) software to automate sales activities. A mobile-based SFA model that can be done up to the countryside or rural areas was recently introduced by Dissanayaka (2019).

Some banking companies design web-based monitoring tools to accommodate the company's needs only, without paying attention to the sales force's needs. It only monitors monthly sales results, while performance is reviewed only at the beginning of the following month. Unfortunately, these webbased monitoring tools cause salespeople to see the achievement of targets manually or from a separate report. Meanwhile, the SPM dashboard is made for the company's needs, and besides that, it can also accommodate the sales force's needs where it helps sales forces measure the ability to achieve targets, plan sales and customer approaches strategies, and increase work motivation. Also, raise awareness of developing skills, and providing up-to-date information to supervisors about sales force performance to determine the proper training.

Although the SPM dashboard design in this study was developed using excel software synchronized with Microsoft OneDrive looks simple. Still, the concept offered to monitor sales process activities, sales results, and performance rate daily was a new concept that allows it to be developed using more sophisticated software. Furthermore, the importance of the SPM dashboard is from a visual sales funnel that can detect the progress of the approach to potential customers. Based on this, the sales force can decide the appropriate approach strategy through communications with the supervisor. In addition, a cash-out column for consumer funds helps the sales force know the sales results so they can plan several sales strategies to achieve the targets.

Further research will implement this dashboard design to address the issue of achieving monthly targets in the sales division of an Islamic banking company and measure their performance after implementation.

Conceptualization: Mardhiah Gani

\section{AUTHOR CONTRIBUTIONS}

Data Curation: Mardhiah Gani

Formal Analysis: Mardhiah Gani, Kifayah Amar, Rosmalina Hanafi

Funding Acquisition: Mardhiah Gani

Investigation: Mardhiah Gani

Methodology: Mardhiah Gani

Project Administration: Mardhiah Gani, Kifayah Amar, Rosmalina Hanafi

Resources: Mardhiah Gani

Software: Mardhiah Gani

Supervision: Mardhiah Gani, Kifayah Amar, Rosmalina Hanafi

Validation: Mardhiah Gani, Kifayah Amar, Rosmalina Hanafi

Visualization: Mardhiah Gani, Kifayah Amar, Rosmalina Hanafi

Writing - Original Draft: Mardhiah Gani

Writing - Review \& Editing: Kifayah Amar, Rosmalina Hanafi 


\section{CONFLICT OF INTEREST STATEMENT}

The authors declare that they have no competing interests.

\section{ACKNOWLEDGEMENT}

All authors contributed equally to the conception and design of the study.

\section{REFERENCES}

Agnihotri, R., \& Rapp, A. (2010). Effective Sales Force Automation and Customer Relationship Management, New York: Business Expert Press LLC.

Barker, R. M., Gohmann, S. F., Guan, J., \& Faulds, D. J. (2009). Why is my sales force automation system failing? Business Horizons, 52(3), 233-241. https://doi.org/10.1016/j.bushor.2009.01.001

Baysan, C., Bertman, A., Maynigo, R., Norville, G., Osborne, N., \& Taylor, T. (2005). The design and development of a sales force automation tool using business process management software. Proceedings of the 2005 IEEE Systems and Information Engineering Design Symposium, 318-327. https://doi.org/10.1109/sieds.2005.193274

Beltran, D. J., Kangleon, Y., Balan, A. K., \& De Goma, J. (2021). Credit card sales performance dashboard. Proceedings of the International Conference on Industrial Engineering and Operations Management (pp. 1-12), Singapore. Retrieved from https://scholar.google.co.id/scholar?hl=en\&as_sdt=0\%2C5\&q=Credit+Card+Sales+Performance+ Dashboard $+\&$ btnG $=$

Berry, L. L. (2002). Relationship Marketing of Services Perspectives from 1983 and 2000. Journal of Relationship Marketing, 1(1), 59-77. https://doi.org/10.1300/J366v01n01_05

Borg, S. W., \& Young, L. (2014). Continuing the evolution of the selling process: A multi-level perspective. Industrial Marketing Management, 43(4), 543-552. https://doi.org/10.1016/j.indmarman.2014.02.013

Boujena, O., Johnston, W. J., \& Merunka, D. R. (2009). The benefits of sales force automation: A customer's perspective. Journal of Personal Selling and Sales Management, 29(2), 137-150. https://doi.org/10.2753/PSS0885-3134290203

Department of Islamic Banking. (2015). Indonesia's Islamic Banking Roadmap 2015-2019.Pdf (p. 53). Retrieved from https:/www.ojk.go.id/id/kanal/syariah/berita-dankegiatan/publikasi/Documents/roadmap-pbs_2015-2019.pdf

Dissanayaka, D. M. M. S. D. (2019). Sales Force Mobile Application for Arpico Local Manufacturing and Distribution Sector (Unpublished master theses) University of Colombo, Colombo, Srilanka.

Financial Services Authority. (2018). Indonesian Islamic Banking Snapshot, 1-8. Retrieved from https://www.ojk.go.id/id/kanal/syariah/berita-dan-kegiatan/publikasi/Documents/Pages/SnapshotPerbankan-Syariah-Indonesia-Desember-2018/ 
Grublješič, T., \& Čampa, N. (2016). The impact of the IS on the effectiveness of the Sales Funnel Management as a part of CRM in an automotive company. Online Journal of Applied Knowledge Management, 4(2), 74-92. https://doi.org/10.36965/ojakm.2016.4(2)74-92

Jelinek, R. (2013). All pain, no gain? Why adopting sales force automation tools is insufficient for performance improvement. Business Horizons, 56(5), 635-642. https://doi.org/10.1016/j.bushor.2013.06.002

Malek, S. L., Sarin, S., \& Jaworski, B. J. (2018). Sales management control systems: review, synthesis, and directions for future exploration. Journal of Personal Selling and Sales Management, 38(1), 3055. https://doi.org/10.1080/08853134.2017.1407660

Pauwels, K., Ambler, T., Clark, B. H., LaPointe, P., Reibstein, D., Skiera, B., Wierenga, B., \& Wiesel, T. (2009). Dashboards as a service: Why, what, how, and what research is needed? Journal of Service Research, 12(2), 175-189. https://doi.org/10.1177/1094670509344213

Roff-Marsh, J. (2004). How to build a high-throughput sales process. Proceedings of the Theory of Constraints International Certification Organization Conference, Miami, Florida. Retrieved from https://salesprocessengineering.net/2008/07/18/how-to-build-a-high-throughput-salesprocess/

Rostamian, B., \& Sadrabadi, M. M. (2016). The Relation between Social Intelligent and Service Presentation Quality (Case Study: Selected Branches of Melat Bank of Isfahan City). Procedia Social and Behavioral Sciences, 230(May), 290-297. https://doi.org/10.1016/j.sbspro.2016.09.037

Stoop, J. (2009). Developing a reference model for KPI and Dashboard reporting in Sales \& Marketing. University of Twente, Enschede, Netherlands. Retrieved from http://essay.utwente.nl/60699/

Yan, J., Gong, M., Sun, C., Huang, J., \& Chu, S. M. (2015). Sales pipeline win propensity prediction: A regression approach. Proceedings of the 2015 IFIP/IEEE International Symposium on Integrated Network Management, IM 2015, 854-857. https://doi.org/10.1109/INM.2015.7140393

\section{Copyrights}

Copyright for this article is retained by the author(s), with first publication rights granted to the journal. This is an open-access article distributed under the terms and conditions of the Creative Commons Attribution license (https://creativecommons.org/licenses/by/4.0). 